\title{
METAKOGNITIF PADA PROSES BELAJAR ANAK DALAM KAJIAN NEUROSAINS
}

\author{
Ruqoyyah Fitri \\ Program Studi PG PAUD, Fakultas Ilmu Pendidikan, Universitas Negeri Surabaya \\ E-mail: ruqoyyahfitri@unesa.ac.id
}

\begin{abstract}
Abstrak
Kajian ini bertujuan menguraikan perkembangan metakognitif pada anak usia dini yang dikembangkan melalui bermain dan dikaitkan dengan teori neurosains agar dapat dipahami bagaimana anak belajar sesuai dengan cara kerja otak. Metode pembahasan menggunakan studi literatur dengan menguraikan, merangkum dan menuangkan gagasan dari beberapa sumber pustaka baik berupa teori, temuan dan bahan penelitian yang relevan dan mutakhir. Dari studi literatur yang dilakukan dapat diketahui bahwa kemampuan metakognitif anak berkembang sejak usia 2 tahun, yaitu ketika anak telah menyadari adanya pikiran. Karenanya meningkatkan proses berpikir pada dasarnya adalah mengembangkan metakognitif. Kemampuan metakognitif anak tidak muncul dg sendirinya, tapi dilatihkan sehigga menjadi kebiasaan. Proses metakognitif anak dilatihkan melalui kegiatan bermain mulai dari yang sederhana sampai ke yang lebih rumit. Keterampilan metakognitif berkaitan erat dengan neurosains yang membahas tentang kinerja otak. Terjadinya proses berpikir tingkat tinggi yang merupakan keterampilan metakognitif seseorang adalah tugas dari bagian depan otak yang disebut dengan lobus prefrontal. Belahan otak bagian depan ini dikenal sebagai pusat kontrol eksekutif atau pusat terjadinya berpikir tingkat tinggi. Juga tempat upaya pemecahan masalah, regulasi demensi emosi, penentu watak dan karakter serta kepribadian seseorang. Dalam hal ini guru dan orang tua harus memperhatikan beberapa masa peka anak yang mendukung proses metakognitif sebagai pedoman pengelolaan pembelajaran di kelas diantaranya; (1) kontrol emosi, dengan menciptkan suasana emosi senang, (2) kontrol kognitif, dengan memilih metode yang mendukung kinerja otak, dan (3) kontrol motorik, dengan melibatkan gerak fisik dalam proses pembelajaran.
\end{abstract}

Kata Kunci: metkognitif, proses belajar, neurosains

\section{Abstract}

This study aims to describe metacognitive development in early childhood that is developed through play and is associated with the theory of neuroscience in order to understand how children learn according to how the brain works. The method of discussion using literature study by describing, summarize and pour ideas from several sources of literature in the form of theory, findings and relevant research materials and current. From literature studies conducted can be seen that the metacognitive ability of children develop since the age of 2 years, when the child has realized the mind. Hence improving the thinking process is basically developing metacognitive. The child's metacognitive abilities do not appear on their own, but are trained as a habit. The child's metacognitive process is trained through play activities ranging from simple to more complicated. Metacognitive skills are closely related to neuroscience that discusses the performance of the brain. The occurrence of a high-level thinking process that is a person's metacognitive skills is the task of the front of the brain called the prefrontal lobe. The frontal hemispheres are known as executive control centers or centers of higher-order thinking. It is also a place for problem-solving, emotional demands regulation, determinants of character and character and personality. In this case teachers and parents should pay attention to some child-sensitive periods that support metacognitive processes as guidelines for the management of learning in the classroom among others; (1) emotional control, by creating a happy emotional atmosphere, (2) cognitive control, by selecting methods that support brain performance, and (3) motor control, by involving physical motion in the learning process

Keywords: metacognitive, learning processes, neurosains

\section{PENDAHULUAN}

Penelitian-penelitian yang telah dilakukan oleh para ahli menunjukkan bahwa ketrampilan metakognitif muncul sekitar usia 8 - 10 tahun dan didahului oleh kemampuan kognitif lain seperti perkembangan Theory of Mind (ToM) (Whitebread, dkk, 2010). Proses metakognitif pada anak dilatihkan melalui kegiatan bermain dimana bermain adalah kegiatan yang sangat penting bagi pertumbuhan dan perkembangan anak. Bagi anak, bermain sejatinya adalah perwujudan dari proses belajarnya. Bermain harus dilakukan dengan rasa senang dan atas inisiatifnya sendiri, sehingga semua kegiatan bermain akan menghasilkan proses belajar anak. Anak belajar melalui permainan mereka. Pengalaman bermain yang menyenangkan dengan bahan, benda, anak lain, dan dukungan orang dewasa membantu anak-anak berkembang secara optimal.

Sesuai teori Piaget dalam Muthiah (2010:101), bermain bukan saja mencerminkan sikap perkembangan kognisi anak, tetapi juga memberikan sumbangan 
terhadap perkembangan kognisi itu sendiri. Dalam prakteknya anak melakukan proses bermainnya dari yang sederhana menuju yang lebih rumit hingga mencoba memanipulasi lingkungan dan mencoba hal-hal yang baru. Bahkan mereka mampu menggeneralisasikan satu situasi ke situasi lain. Dengan teknik tertentu pada akhirnya anak mampu membawakan dirinya untuk menguasai berbagai rintangan di lingkungan barunya tersebut (Suyadi, 2010:). Rintangan tidak hanya berupa fisik tapi juga bersifat mental (seperti kemandirian, tanggung jawab, pengetahuan) serta bahasa, etika maupun estetika. Semua rintangan di lingkungan anak merupakan tugas perkembangan yang harus dituntaskan. Rintangan di lingkungan anak dengan istilah lain permasalahan belajar menuju kematangan perkembangan, dapat dilalui anak dengan mengoptimalkan proses berpikirnya secara bertahap.

Proses dan tahapan berpikir anak dalam memecahkan pemasalahan belajarnnya menuju kematangan perkembangan tersebut merupakan kemampuan metakognitif mereka. Metakognitif merupakan kesadaran seseorang tentang proses berpikirnya pada saat melakukan tugas tertentu kemudian menggunakan kesadaran tersebut untuk mengontrol apa yang dilakukan.

Proses metakoknitif pada anak usia dini sesuangguhnya didahului oleh kemampuan kognitif lain seperti perkembangan Theory of Mind (ToM) (teori tentang pemikiran). Piaget dalam teorinya (dalam Fatana, 2016) menyatakan bahwa masa kanak-kanak awal dari sekitar usia 2 sampai 6 tahun sebagai tahap Praoperasional, karena anak-anak belum siap untuk terlibat dalam operasi atau manipulasi mental yang mensyaratkan pemikiran logis.

Menurut Preisseisen (dalam Paulina Panen dkk. 2001 dalam Susanto, 2015) metakognitif terdiri dari 4 keterampilan: decision making, critical thinking, creative thinking, problem solving. Mengambil keputusan, berfikir kritis, berfikir kreatif, dan memecahkan masalah. Pendekatan keterampilan proses dan pemecahan masalah hendaknya dilatihkan sejak usia dini. Contoh: anak diajak untuk merefleksikan kegaiatan yang baru dilakukan, atau bacaan yang selesai dibaca, dengan cara dikemas menjadi kegiatan yang menyenangkan. Karenanya bisa dikatakan bahwa dalam metakognitif ada strategi kognitif (Bahri, 2008). Contohnya ketika mengajak anak mandi bisa diberi pilihan mandinya sama siapa. Dari situ bisa memberi kesempatan anak untuk berpikir dan melatihnya untuk belajar mengambil keputusan.

Keterampilan metakognitif dapat membantu mengembangkan kemampuan berpikir anak yang selanjutnya juga berpengaruh terhadap hasil belajarnya (Ardila, et al., 2013). Mengajarkan keterampilan berpikir pada anak sangat penting karena kemampuan berpikir anak belum berkembang sempurna serta belum mampu menerapkan berbagai keterampilan berpikir dalam situasi yang bervariasi dan belum mampu secara spontan menunjukkan kemampuan ini. Burke \& Williams, (2009) dalam Burke, et.al (2012:146) mengungkapkan bahwa anak-anak cenderung belum mampu mengasosiasikan kepandaian dengan penerapan keterampilan berpikirnya. Karena itu, dibutuhkan intervensi di kelas yang diarahkan untuk menumbuhkan keterampilan berpikir anak yang mengarahkan pada usaha pencapaian kecerdasannya dengan cara melatihkan kemampuan metakognitif anak.

Senada dengan penelitian yang dilakukan oleh Flavel, Tianingsih (2016) menyatakan bahwa kemampuan metakognitf anak tidak muncul dengan sendirinya, tetapi memerlukan latihan. Peran orang tua dan guru sebagai teladan yang berperan melatihkan kemampuan tersebut sehigga menjadi kebiasaan. Proses metakognitif anak diantaranya bisa dilatihkan melalui kegiatan bermain mulai dari yang sederhana sampai ke yang lebih rumit.

Suherman (2001:96) menyatakan bahwa perkembangan metakognitif dapat diupayakan melalui cara dimana anak dituntut untuk mengobservasi tentang apa yang mereka ketahui dan kerjakan, dan untuk merefleksi tentang apa yang dia observasi.. Oleh karena itu, sangat penting bagi guru atau pendidik (termasuk orang tua) untuk mengembangkan kemampuan metakognitif baik melalui pembelajaran ataupuan mengembangkan kebiasaan di rumah. Beberapa peran metakognitif dalam proses belajar anak seperti berikut :

\section{Peran Metakognitif dalam Pembelajaran Bahasa}

Pembelajaran bahasa yang memiliki kaitan dengan matekognitif adalah strategi membaca buku. Membaca buku adalah aktivitas yang menuntut strategi agar dapat membaca secara efisien. Aktivitas membaca yang efektif harus mengikuti langkah-langkah tertentu. Pertama, menetapkan tujuan membaca; kedua, menetapkan urutan membaca bagian-bagian buku; dan ketiga, menetapkan strategi membaca agar efektif. Langkah-langkah ini menuntut aktivitas metakognitif karena siswa yang membaca harus menentukan terlebih dahulu strategi apa yang akan dia gunakan. Anak yang dilatih strategi membaca akan lebih mudah membaca buku dan mudah memahami buku dibandingkan dengan anak yang tidak menggunakan strategi.

\section{Peran Metakognitif dalam Pembelajaran Matematika}

Lester (dalam Goos et.al., 2000:1) mengungkapkan bahwa salah satu kajian yang menarik dalam topik pemecahan masalah adalah peran metakognitif dalam pemecahan masalah. Goos et.al. (2000) melakukan penelitian tentang peran metakognitif bagi siswa dalam 
kegiatan memecahkan masalah matematika. Mereka melakukan investigasi terhadap strategi siswa metakognitif siswa sekolah menengah ketika mereka memecahkan masalah matematika secara individu. Siswasiswa diberikan soal matematikan dan mereka kemudian menyelesaikannya secara individu. Setelah siswa menyelesaikan soal tersebut, kemudian diberikan angket sebagai instrumen untuk mengetahui aktivitas metakognitif siswa.

Untuk mengetahui aktivitas metakognitif siswa digunakan instrumen monitoring diri metakognisi yang memuat pernyataan-pernyataan metakognitif. Misalnya, saya yakin bahwa saya memahami masalah yang ditanyakan pada saya; saya mencoba menyajikan masalah dengan bahasa saya sendiri; saya mencoba untuk mengingat jika saya pernah menyelesaikan masalah yang mirip dengan masalah seperti ini; saya mengidentifikasi dan memeriksa setiap informasi yang terdapat dalam masalah ini; serta saya berpikir tentang pendekatan yang berbeda yang akan saya coba untuk mecahkan masalah ini. Siswa diminta untuk menyatakan "ya", "tidak" atau "mungkin". Dari penelitian itu disimpulkan bahwa siswa yang menggunakan strategi metakognitifnya dengan baik ketika menyelesaikan soal matematika (pemecahan masalah) memiliki kemampuan lebih dalam menyelesaikan soal matematika. Siswa tersebut berusaha untuk menggunakan metakognitifnya untuk mengatur langkah-langkah berpikir dalam menyelsaikan soal matematika.

Pada anak usia dini aktivitas metakognitif yang senada dengan belajar matematika adalah katika anak membangun puzzle ia membuat banyak metakognitif (Marulis, 2016:27). Ketika anak mengalami masalah dalam membangun puzzle dia akan berusaha untuk berpikir dan melakukan kegiatan memonitor dirinya apa yang salah dari letak kepingan puzzle tersebut sehingga bangnan tidak berbentuk. Melalui proses berpikir dan mencoba berulang-ulang akhirnya anak bisa menyelesaikan puzzle tersebut dengan benar.

\section{Peran Metakognitif dalam Pembelajaran Kemandirian}

Kemandirian sangat dipengaruhi oleh kepercayaan diri. Dalam riset terbaru mengenai perkembangan kepercayaan diri dan kepercayaan antara anak dengan orang tua ditemukan bahwa jika anak merasa aman, maka anak akan lebih mau melakukan penjelajahan sendiri, lebih mampu mengelola stress, mempelajari ketrampilan baru, dan berhubungan dengan orang lain serta memiliki kepercayaan lebih bahwa mereka cukup kompeten untuk menghadapi lingkungan yang baru. Dengan mendorong penjelajahan, akan menunjukkan bahwa mereka dipercaya oleh orang dewasa untuk melakukan apa yang ditawarkan oleh kehidupan yang dia alami. Selanjutnya mereka akan mencoba dan bereksperimen dengan benda-benda, orang yang pada akhirnya akan muncul ide-ide baru mereka. sehingga mereka terdorong melakukan semua tindakan tanpa rasa takut disalahkan oleh orang dewasa di sekitarnya.

Berdasarkan uraian di atas menunjukkan pentingnya keterampilan metakognitif untuk dilatihkan sejak anak usia dini sampai menjadi suatu kebiasaan. Untuk itu diperlukan pengetahuan tentang bagaimana metakognitif pada proses belajar anak usia dini yang dihubungkan dengan neurosain sehingga dapat memberi wawasan bagi guru dan orang tua dalam mendampingi anak untuk belajar lebih optimal.

\section{PEMBAHASAN}

\section{Pengertian Metakognitif}

Flavell mendefinisikan metakognisi sebagai pengetahuan tentang objek-objek kognitif, yaitu tentang segala sesuatu yang berhubungan dengan kognisi. Flavell dalam Iwai (2011: 151) juga mengungkapkan bahwa metakognitif adalah pengetahuan seseorang mengenai proses berpikir dan hasil berpikirnya atau apapun yang berkaitan dengan proses dan hasil berpikir tesebut. Wells (2009:1) mengungkapkan bahwa metakognisi adalah pikiran yang diaplikasikan untuk pikiran. Atau dengan kata lain, metakognitif adalah berpikir tentang berpikir.

Pertama kali, konsep metakognisi diperkenalkan oleh John Flavell pada tahun 1976 (Malone, 2007:7). Flavell mendefinisikan metakognisi sebagai pengetahuan tentang objek-objek kognitif, yaitu tentang segala sesuatu yang berhubungan dengan kognisi. Dikalangan para ahli psikologi timbul perdebatan pada pendefinisian dari istilah metakognisi. Hal ini berakibat bahwa metakognisi tidak selalu sama didalam berbagai bidang penelitian psikologi, dan juga tidak dapat diterapkan pada satu bidang psikologi saja. Namun, pengertian metakognisi yang dikemukakan oleh para peneliti bidang psikologi memberikan penekanan pada kesadaran berpikir seseorang tentang proses berpikirnya.

Menurut Brown (Zohar, 1999:414) mengungkapkan bahwa metakognitif mengarah pada pemahaman tentang pengetahuan, suatu pemahaman yang dapat direfleksikan dari penggunaan efektif atau deskripsi pengetahuan yang jelas pada pertanyaan. Artinya, metakognitif pada dasarnya berkaitan dengan pemahaman seseorang tentang pengetahuan yang dimilikinya. Pemahaman tersebut diperoleh atas dasar refleksi yang dilakukan oleh dirinya sendiri berkaitan dengan penggunaan strategi yang efektif atau deskripsi yang jelas dari strategi-strategi yang digunakan dalam menjawab suatu pertanyaan atau soal. Sebagai tambahan, Quirk (2006:4) mengungkapkan 
bahwa metakognitif adalah adalah kemampuan seseorang untuk berpikir tentang pikiran dan perasaannya sendiri dan untuk memprediksi apa yang orang lain pikirkan.

Sedangkan menurut Ozsoy \& Ataman (2009: 68) mengartikan metakognisi merupakan kesadaraan seseorang mengenai proses berpikirnya dan kemampuannya untuk mengontrol proses tersebut. Selain itu, Schraw \& Dennison (1994: 460) menyatakan bahwa metakognisi merupakan kemampuan untuk merefleksikan tentang, memahami, dan mengontrol belajar seseorang. Mengontrol belajar akan mengakibatkan seseorang bisa mengendalikan apa yang mereka lakukan dalam kegiatan belajarnya. Adapun Woolfolk (2009:35) berpendapat bahwa metakognisi melibatkan pengetahuan dan kesadaran seseorang tentang aktivitas kognitifnya sendiri atau segala sesuatu yang berhubungan dengan aktivitas kognitifnya. Secara sederhana, metakognisi adalah pengetahuan tentang proses kognisi. Lebih rinci, metakognisi adalah pengetahuan, kesadaran, dan kendali atas proses kognisi. Metakognisi mempunyai peranan sebagai suatu bentuk representasi kognisi yang didasarkan pada proses memonitor dan mengontrol berdasarkan representasi kognisi.

Dari pendapat para ahli di atas, dapat disimpulkan bahwa metakognisi sebagai kemampuan seseorang dalam belajar, yang mencakup bagaimana sebaiknya belajar dilakukan, apa yang sudah dan belum diketahui, yang terdiri dari tiga tahapan yaitu perencanaan mengenai apa yang harus dilakukan, memantau perkembangan diri dalam belajar; dan menilai apa yang dipelajari.

Berdasarkan definisi yang telah dikemukakan pada uraian di atas dapat diidentifikasi pokok-pokok pengertian metakognisi sebagai berikut:

1. Metakognisi merupakan kemampuan jiwa yang termasuk dalam kelompok kognisi.

2. Metakognisi merupakan kemampuan untuk menyadari, mengetahui proses kognisi yang terjadi pada diri sendiri.

3. Metakognisi merupakan kemampuan untuk mengarahkan proses kognisi yang terjadi pada diri sendiri

4. Metakognisi merupakan kemampuan untuk belajar bagaimana mestinya belajar dilakukan yang meliputi proses perencanaan, pemantauan, dan evaluasi

5. Metakognisi merupakan aktivitas berpikir tingkat tinggi karena aktivitas ini mampu mengontrol proses berpikir yang sedang berlangsung pada diri sendiri.

\section{Metakognitif Pada Proses Belajar Anak}

Secara historis metakognitif pada anak usia dini kurang menjadi perhatian. Padahal kemampuan metakognitif anak bisa dikembangkan dan bisa diukur.
Hanya baru-baru ini saja para peneliti mulai mendeteksi secara konkrit metakognitif anak usia $3-5$ tahun menggunakan alat penilaian observasi. Seiring dengan berjalannya waktu Secara umum metode observasi lebih peka untuk megetahui metakognitif anak. Namun penggunaan metode observasi kurang mampu memberikan gambaran menyeluruh kemampuan metakognitif anak secara detail. Karenanya Marulis, et.al (2016) melakukan penelitian ini untuk pengembangan kemampuan metakognitif anak melalui wawancara.

Mengingat anak-anak mempunyai metakognisi yang terbatas dan mereka jarang memonitor memori, bahasa, problem solving, atau mengambil keputusan (Flavell, 1990). Karenanya penelitian terakhir pada metakognisi anak lebih difokuskan pada topik yang disebut teori berpikir (theory of mind), tentang bagaimana pikiran mereka bekerja dan pada keyakinan mereka tentang pemikiran orang lain (Bartsch dan Wellman, 1995; Flavell 1999; Schneir dan Pressley, 1997). Pada dasarnya kemampuan metakognitif tumbuh dan berkembang seiring dengan pertambahan usia. Secara umum, kemampuan metakognitif mulai berkembang pada usia sekitar 5 hingga 7 tahun (Woolfolk, 2008). Sedangkan menurut Whitebread, dkk, (2010) bahwa ketrampilan metakognitif muncul sekitar usia 8 - 10 tahun dan didahului oleh kemampuan kognitif lain seperti perkembangan Theory of Mind (ToM) .

Teori berpikir (theory of mind) yang merupakan bagian dari metakognitif anak sangat berkaitan dengan kemampuan intelektual. Model Piaget tentang perkembangan intelektual menjelaskan adanya perkembangan, sehingga kecerdasan dibangun dalam suatu kurun waktu dalam rangkaian yang tersusun dari tahapan-tahapan yang saling terkait atau berhubungan, dan tiap tahap ini menentukan perkembangannya. Perkembangan ini merupakan proses fundamental dimana tiap elemen dari pembelajaran sebagai fungsi dari perkembangan secara keseluruhan. Sehingga, perkembangan intelektual seseorang menentukan apa yang bisa dipelajarinya pada taraf itu.

Merujuk pada hasi penelitian bahwa ketrampilan metakognitif muncul sekitar usia $8-10$ tahun dan didahului oleh perkembangan Theory of Mind (teori tentang pemikiran) sejalan dengan teori Piaget. Bahwa Piaget dalam teorinya (dalam Fatana, 2016) menyatakan masa kanak-kanak awal dari sekitar usia 2 sampai 6 tahun sebagai tahap Praoperasional, karena anak-anak belum siap untuk terlibat dalam operasi atau manipulasi mental yang mensyaratkan pemikiran logis. Jean piaget menjelaskan tentang perkembangan kognitif anak praoprasional sebagai berikut (Fatanah, 2016) : 
1. Pengetahuan tentang Berpikir dan Kondisi mental

Antara usia 3 dan 5 tahun anak-anak mulai memahami pikiran yang berlangsung dalam jiwa; bahwa hal tersebut dapat berkaitan dengan hal-hal yang nyata maupun yang bersifat imajiner; bahwa seseorang dapat memikirkan satu hal sambil melakukan atau melihat hal lain; bahwa seseorang yang ditutup mata dan telingannya dapat memikirkan sesuatu; dan berpikir merupakan aktifitas yang berbeda dengan melihat, berbicara, menyentuh,dan mencari tahu (Flavell et al.,1995).

\section{Egosentrisme}

Egosentrisme merupakan bentuk sentrasi. Merujuk kepada Piaget, anak-anak pada masa egosentris sangat terpusat pada sudut pandangnya sendiri sehingga mereka tidak dapat menerima pandangan dari orang lain. anak usia tiga tahun sudah berkurang egosentrisnya dibandingkan bayi yang baru lahir. Akan tetapi, menurut Piaget, masih berpikir bahwa pusat dunia adalah diri mereka. Egoisentrisme mungkin dapat membantu menjelaskan mengapa anak kecil terkadang mengalami masalah dalam membedakan realita dengan apa yang ada diotak mereka dan mengapa mereka menunjukkan kebinggungan terhadap terjadinya sesuatu. Ada dua contoh riset yang akan membantu pemahaman.

Contoh riset pertama, seorang anak duduk didepan meja menghadap tiga tumpukan tanah yang dibentuk menyerupai tiga gunung. Sebuah boneka ditempatkan di kursi yang berhadapan dengan sang anak. Para periset menanyakan pada anak bagaimana agar pegunungan tersebut dapat dilihat oleh boneka. Piaget menemukan bahwa anak kecil biasanya tidak menjawab pertanyaan tersebut secara tepat sebaliknya mereka justru mendeskripsikan gunung tersebut dari pandangan mereka.

Akan tetapi riset lain yang menampilkan masalah yang sama dengan cara yang berbeda memberikan hasil yang berbeda (Hughes1975). Seorang anak didudukkan dihadapan sebuah papan persegi empat yang bagian "dinding". Sebuah polisi mainan ditempatkan diujung papan dan sebuah beneka digerakkan dari satu bagian ke bagian yang lain. Setelah beberapa kali perpindahan boneka itu, anak ditanyai "apakah si polisi dapat melihat boneka?" Kemudian polisi mainan lainnya dibawa untuk beraksi dan si anak diminta untuk menyembunyikan boneka dari kedua petugas tersebut. Tiga puluh anak usia 3 tahun sampai 5 tahun menjawab dengan tepat 9 dan 10 kali

Yang menjadi pertanyaan adalah mengapa anak-anak ini dapat mengambil sudut pandang polisi sedangkan mereka di percobaan pertama tidak dapat melakukan hal tersebut? Mungkin jawabannya adalah tugas dari "petugas kepolisian" lebih akrab dan tidak terlalu abstrak. Bagi sebagian besar anak, gunung masih abstrak karena anak tidak pernah melihat gunung. Anak belum memiliki pengalaman tentang gunung sehingga tidak bisa memikirkan seperti apa yang mungkin dipikirkan oleh orang lain. Sebaliknya sebagian besar anak usia 3 tahun mengenali boneka dan polisi serta tindakan menyembunyikan.

Dari kedua riset tersebut dapat disimpulkan bahwa anak mungkin akan menunjukkan sikap egosentrisme khususnya dalam situasi yang berada diluar pengalaman yang pernah mereka alami. Bila dikaitkan dengan teori pemikiran, bahwa pada masa awal kanak-kanak, mereka sudah mulai bisa menggunakan pemikirannya pada hal yang sifatnya konkrit dan pada sesuatu yang berada pada situasi yang pernah dia alami.

Berdasarkan uraian tentang teori pemikiran dan hasil riset oleh Piaget tersebut di atas menegaskan adanya kaitan antara teori pemikiran (teori of mind) dengan teori metamemori pada anak, bahwa pemikiran anak dipengaruhi oleh metamemorinya. Anak akan mudah mempelajari sesuatu yang sifatnya familiar (sudah dikenal) dari pada mempelajari sesuatu yang tidak familiar (belum dikenal). Dalam proses metamemori ini anak akan menggunakan pemikirannya untuk mempelajari sesuatu dengan menghubungkan pada sesuatu yang dikenal oleh anak. dalam hal ini peran guru sangat menentukan agar bisa menyediakan situasi dan lingkungan belajar yang sudah dikenali anak sehingga bisa meningkatkan kemampuan berpikir mereka. Kegiatan pembelajaran yang dibingkai dengan tema-tema yang dekat dengan anak, menggunakan media konkrit yang banyak dikenal anak, serta mengajak anak untuk melihat langsung obyek belajar, seperti mengajak ke sawah, berkebun, memancing, ke kebun binatang sangat membantu meningkatkan kemampuan berpikir mereka. Dari proses metamemori melalui kegiatan main pada hal konkrit, kontekstual dan dikenal anak, mereka akan mengalami proses mengingat dengan mudah, memahami sesuatu, memikirkan cara dan pemecahan masalah, yang kesemuanya merupakan proses metakognitif.

Kebanyakan studi pengembangan telah mengklasifikasikan "metakognitif" sebagai perwujudan eksplorasi metamemori anak-anak, yaitu pengetahuan mereka tentang memori. Pengetahuan tentang memori juga telah diterapkan untuk meneliti pemahaman anak, komunikasi anak, dan keterampilan pemecahan masalah pada anak (Flavell, 2000; Schneider dan Pressley, 1997) dalam Schneider (2004:224). Pada awal 1980-an, penelitian difokuskan pada anak-anak tentang pengetahuan dunia mental, yang lebih dikenal istilah "teori tentang berpikir (Theory of mind)"

Metamemori secara sederhana berarti di atas atau di luar kelaziman memori dan ia merupakan metakognitif. Strategi metamemori dapat berupa mnemonic devices (muslihat memori), yakni 
bermacam-macam alat rekayasa akal. Mnemonic devices itu berarti kiat khusus yang dijadikan "alat pengait" mental untuk memasukkan item-item informasi ke dalam sistem akal siswa, antara lain: rima (Rhyme), singkatan, sistem kata pasak(paku), metode losai, sistem kata kunci (key word system), dan lain-lain. Contoh dari metamemory adalah pada usia 5 atau 6 tahun, anak-anak biasanya mengetahui bahwa hal-hal yang familar lebih mudah untuk dipelajari dibandingkan hal-hal yang tidak familiar, bahwa daftar yang lebih pendek lebih mudah dipahami dari pada yang panjang, bahwa pengenalan lebih mudah dari pada mengingat kembali, dan bahwa lupa menjadi lebih mungkin seiring berjalannya waktu (Lyon , 2016).

\section{Metakognitif pada Proses Belajar Anak Hubungannya dengan Neurosains}

Neurosains merupakan ilmu yang mempelajari cara kerja otak. Ikrar (2015:1) menyatakan neurosains adalah ilmu yang rumit dan menantang karena menyangkut otak yang menjadi pusat kehidupan. Prinsip dasar neurosains dimaksudkan untuk memberikan pemahaman yang sangat mendasar tentang cara kerja sistem saraf manusia. Para ahli dunia telah mengembangkan dan mendorong kemaujuan neurosains menjadi ilmu modern dan ilmu masa depan yang bisa berimplikasi sangat luas terhadap kehidupan manusia.

Pengertian neurosains lebih dalam disampaikan oleh Hernanta (2013:15) bahwa neurosains merupakan bidang ilmu yang menghususkan pada studi saintifik dari sitem saraf, khususnya otak manusia. Jika dikaitkan dengan perkembangan hakikat diri manusia, neurosains adalah ilmu yang mengkaji diri manusia sebagai proses yang berlangsung pada tingkat sel saraf hingga proses perhubungan manusia dengan Tuhan.

Secara sederhana neurosains bisa diartikan sebagai ilmu yang secara khusus mempelajari dan mengkaji sistem saraf atau sistem neuron (sel saraf) padaa manusia.

Neurosains berkaitan erat dengan keterampilan metakognitif yang merupakan keterampilan berpikir tingkat tinggi. Dalam prosesnya keterampilan metakognitif ini melalui tahapan regulasi emosi, kesadaran, memonitor proses kognisi. Terjadinya proses berpikir tingkat tinggi merupakan tugas dari bagian depan otak yang disebut dengan lobus prefrontal / prefrontal cortex. Belahan otak bagian depan ini dikenal sebagai pusat kontrol eksekutif atau pusat terjadinya berpikir tingkat tinggi. Juga tempat upaya pemecahan masalah, regulasi demensi emosi, penentu watak dan karakter serta kepribadian seseorang (Suyadi, 2014:86)

Perkembangan proses berpikir pada anak diawali dengan perkembangan neuron (sel saraf otak) pada anak yang mengalami perkembangan dalam bentuk koneksi antar neuron lebih banyak dibandingkan orang dewasa. Otak anak usia 0 - 3 tahun membuat koneksi - koneksi baru dengan kecepatan luar biasa, terutama ketika otak mulai menyerap informasi dari lingkungan. Semakin kaya stimulasi dari lingkungan baik berupa permainan, pengasuhan, dan lainnya maka semakin banyak neuron yang berkoneksi.semakin banyak neuron yang berkoneksi maka akan semakin cepat, mendalam, dan bermakna sebuah pembelajaran (Suyadi, 2014:99).

Masa peka anak merupakan jendela kesempatan pada anak untuk menyerap segala bentuk informasi melalui berbagai stimulasi dari lingkungannya. Beberapa masa peka anak yang mendukung proses metakognitif diantaranya :

\section{Kontrol emosi}

Masa peka anak terhadap kontrol emosi terbuka mulai usia 2 - 30 bulan. Sistem emosi (sistem limbik) berkembang lebih cepat dari pada sistem rasional (lobus frontal). Akibatnya sistem emosi lebih unggul dalam kontrol. Contohnya : anak sering marah jika tidaak mendapatkan apa yang diinginkan. Hal ini disebabkan sistem emosinya yang lebih unggul. Regulasi diri pada usia ini belum terbentuk karena sistem rasional belum berkembang (Suyadi, 2014:103).

Bagaimana peran emosi untuk meningkatkan kecerdasan kognitif ? Sejatinya lobus frontal sebagai sitem rasional sebagai bagaian otak yang canggih untuk mengatur kemampuan berpikir apabila sering digunakan maka kerja otak semakin canggih. Peran lobus frontal (otak berpikir) sangat dipengaruhi oleh amigdala (pengontrol emosi). Emosi positif, seperti gembira menyebabkan lobus frontal (otak berpikir) bekerja dengan optimal dan siap melakukn pekerjaan kognitif yang lebih tinggi. Sebaliknya emosi negatif seperti sedih, takut menyebabkan lobus frontal (otak berpikir) tidak bisa bekerja (Murdiani, 2014:12).

Untuk kepentingan belajar, guru harus mengkodisikan emosi anak agar dalam suasana emosi senang sebelum memulai pelajaran supaya kemampuan berpikir anak bisa bekerja dengan optimal.

\section{Kontrol kognitif}

Masa peka anak terhadap kognitif terbuka mulai usia 10 bulan sampai 7 tahun (Gracia, 2014:36). Otak kognitif dan otak emosi saling mendukung. Dalam proses belajar anak usia dini tidak hanya menggunakan pemrosesan materi pelajaran secara kognitif semata melainkan juga menggambarkan pikiran secara emotif. Hal ini sesuai dengan model Taksonomi Bloom Revisi yang menggambarkan bahwa pemikiran emotif seringkali mendapat input dari pikiran kognitif (Suyadi, 2014:152). Misalnya ketika anak berjalan di kegelapan, amigdala di dalam otak yang berfungsi mengatur emosi segera 
mengevaluasi stimulus lingkungan untuk merasakan adanya ancaman. Amigdala akan bereaksi terhadap suara yang mengancam dan suasana yang mencekam.

Daniel Goleman pencetus konsep "Emotional Inteligence" (Kecerdasan Emosional) dalam Gracia (2014:34) menyatakan bahwa manusia mempunyai dua belahan otak. Singkatnya otak kiri berfungsi sebagai otak berfikir sedangkan otak kanan berfungsi sebagai otak emosional. Jika otak kanan distimulasi sehingga menjadi cerdas, maka otak kiri otomatis semakin cerdas. Namun tidak berlaku sebaliknya jika otak kiri yang dicerdaskan, otak kanan tidak otomatis menjadi cerdas. Seorang pakar neurolog Dr. Damasio menyatakan bahwa otak kanan (otak yang merasakan atau otak meosional) dibutuhkan untuk megambil keputusan rasional. Kemampuan otak measakan otak emosi ini akan menuntun kognitif pada arah yang tepat.

Kemampuan regulasi diri dalam proses metakognitif merupakan kerja otak kanan yang mengarahkan kerja otak kiri untuk melakukan monitor terhadap permasalahan yang dihadapi. proses ini akan mengembangkan kemampuan berpikir anak untuk mencari cara pemecahan masalah tersebut. Disinilah keterampilan metakognitif anak terbentuk. Proses ini merupakan kaitan antara neurosains dalam hal cara cara kerja otak dengan keterampilan metakognitif.

Untuk mengontrol kognitif, dalam proses pembelajaran guru hendaknya memperhatikan bagaimana proses berpikir anak. Berpikir menjadi sebuah proses untuk kepekaan dan meningkatkan kinerja otak menjadi semakin baik. Untuk meningkatkan proses berpikirnya manusia harus belajar. Proses belajar pertama bagi anakanak dengan proses meniru (shadowing), yaitu bagaimana anak meniru segala sesuatu di luar dia. Pola asuh dan metode pengajaran sangat menentukan kemampuan kognitif anak. Metode pengajaran untuk anak usia $0-6$ tahun adalah dengan melibatkan mereka dalam kegiatan belajar. Anak bisa diajak memilih materi yang akan dieksplorasi sehingga anak mendapat inspirasi dan belajar mengambil keputusan sendiri (Gracia, 2014:23-24).

Beberapa metode pengajaran yang sesuai dengan tahap usia anak menurut Gracia (2014:24) :

a. Metode untuk anak uisa $0-3$ tahun : memperhatikan komunikasi guru dengan anak, bagaimana komunikasi guru ketika mengajar agar tidak mendominasi kegiatan anak.

b. Metode untuk anak usia 3 - 5 tahun : memberi kesempatan anak mengobservasi sesuatu. Guru tidak selalu memberi contoh lalu anak mengikuti. Biarkan anak mencoba-coba, sambil guru mengenalkan kosa kata baru dan membiarkan mereka merangkai kalimat.

c. Metode untuk anak usia 6 - 12 tahun : perbanyak melatih kemampuan anak bercerita dan mempresentasikan apa yang mereka ketahui. Metode belajar lebih ditekankan pada bagaimna anak berpikir kreatif. Misalnya ketika menjelaskan suatu hal / benda bisa dengan metode mind mapping (membuat jaring topik). Anak diminta memaparkan satu persatu pengetahuannya tentang meja mulai dari berbagai bentuk, fungsi sampai jumlah penyangganya.

Penggunaan metode-metode dalam proses belajar yang menfasilitasi berkembangnya proses berpikir anak sesuai dengan tahap usia mereka akan mampu meningkatkan keterampilan metakognitif anak.

\section{Kontrol Motorik}

Perkembangan motorik adalah kemampuan gerak, baik gerak motorik halus (meremas, menggenggam) maupun motorik kasar (merangkak, berjalan). Masa peka ini berlangsung selama masa perkembangan fetus (bayi sebelum lahir) hingga usia 6 tahun. Kemampuan motorik melibatkan kerjasama jaringan saraf yang kompleks. Termasuk mengintegrasikan sensor keseimbangan yang terletak pada telinga dalam, serta sinyal output yang dikirim melalui otot-otot tangan dan kaki dalam bentuk stimulasi dari luar (Suyadi, 2014:102).

Apa kaitan latihan fisik motorik bagi peningkatan kinerja otak ? Mengacu pada hasil riset terbaru yang mengindikasikan bahwa otak kecil (cerebelum) yang berfungsi pengontrol motorik juga bertindak mendukung fungsi limbik (pengatur fokus perhatian dan pengontrol denyut) serta mendukung proses kognitif pada lobus frontal. Hasil studi ini menggeser riset lama yang menyatakan bahwa peran otak kecil terbatas untuk mengoordinasikan gerakan tubuh bersama korteks motorik.

Gambar 1. Perbandingan Riset Fisik Motorik (Sausa, 2012:274)

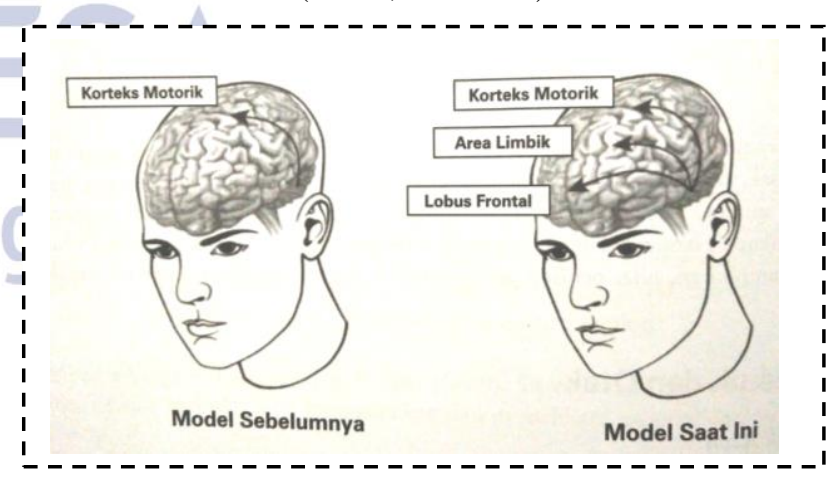

Latihan fisik sederhana dapat meningkatkan jumlah pembuluh darah kapiler kedalam otak yang berperan mempermudah transportasi darah ke otak sehingga jumlah oksigen yang dibutuhkan otak sebagai bahan bakar bisa meningkat. Konsentrasi oksigen mempengaruhi kemampuan otak dalam kinerjanya. Hasil riset menunjukkan bahwa semakin tinggi jumlah oksigen dalam darah di otak akan semakin meningkatkan kinerja 
kognitif. Anak akan mampu menghafal lebih banyak, dan lebih cepat mengerjakan tugas visual dan spasial.

Pada saat berjalan, otak kecil, korteks motorik, dan otak tengah bekerja sama untuk mengordinasikan gerakan tubuh yang diperlukan untuk berjalan. Ketiga komponen otak ini saling mengkoordinasi dan menstimulasi jalan pikiran dengan memacu neuron agar menghidupkan sinyal ke seluruh jaringan. Karenanya terkadang bisa muncul ide kreatif saat berjalan santai (Sausa, 2012:274-275). Untuk meningkatkan kualitas belajar dan meningkatkan kemampuan berpikir kreatif selayaknya kegiatan pembelajaran tidak hanya dengan duduk melainkan ada aktifitas gerak fisik sehingga mengoptimalkan kinerja lobus frontal sebagai otak berpikir.

\section{PENUTUP}

\section{Simpulan}

Metakognitif merupakan pengetahuan dan kesadaran seseorang tentang aktivitas kognitifnya sendiri atau segala sesuatu yang berhubungan dengan aktivitas kognitifnya.. Metakognitif mempunyai peranan sebagai suatu bentuk representasi kognisi yang didasarkan pada proses memonitor dan mengontrol berdasarkan representasi kognisi. Proses kognitif yang terjadi dalam diri anak akan berubah sejalan dengan perkembangan anak tersebut. Perkembangan kognitif sangat erat kaitannya dengan kemampuan berpikir. Meningkatkan proses berpikir pada dasarnya adalah mengembangkan metakognitif seseorang. Kaitan antara metakognitif dengan strategi berpikir adalah bahwa kemampuan metakognitif menyediakan cara mengendalikan berpikir yang pada akhirnya akan menghasilkan kemampuan dalam berpikir kritis.

Metakognisi anak lebih difokuskan pada teori berpikir (theory of mind), tentang bagaimana pikiran mereka bekerja dan pada keyakinan mereka tentang pemikiran orang lain. Teori tentang berpikir ini sejalan dengan teori Piaget yang menegaskan adanya kaitan antara teori pemikiran (teori of mind) dengan teori metamemori pada anak, bahwa pemikiran anak dipengaruhi oleh metamemorinya. Anak akan mudah mempelajari sesuatu yang sifatnya familiar (sudah dikenal) dari pada mempelajari sesuatu yang tidak familiar (belum dikenal). Dalam hal ini peran guru sangat menentukan agar bisa menyediakan situasi dan lingkungan belajar yang sudah dikenali anak seperti membuat kegiatan pembelajaran yang dibingkai dengan tema-tema yang dekat dengan anak sehingga bisa meningkatkan kemampuan berpikir mereka. Dari proses metamemori melalui kegiatan main pada hal konkrit, kontekstual dan dikenal anak, mereka akan mengalami proses mengingat dengan mudah, memahami sesuatu, memikirkan cara dan pemecahan masalah, yang kesemuanya merupakan proses metakognitif.
Metakognitif dalam proses belajar anak sangat berkaitan dengan neurosains, yaitu ilmu yang mempelajari cara kerja otak. Dalam hal ini guru dan orang tua harus memperhatikan beberapa masa peka anak yang mendukung proses metakognitif diantaranya ; (1) kontrol emosi, untuk kepentingan belajar, guru harus mengkodisikan emosi anak agar dalam suasana emosi senang sebelum memulai pelajaran supaya kemampuan berpikir anak bisa bekerja dengan optimal, (2) kontrol kognitif, untuk kepentingan belajar guru harus menerapkan metode pembelajaran yang mendukung peningkatan kinerja otak dengan memperhatikan tahap usia anak, (3) kontrol motorik, bahwa otak kecil (cerebelum) yang berfungsi pengontrol motorik juga bertindak mendukung fungsi limbik (pengatur fokus perhatian dan pengontrol denyut) serta mendukung proses kognitif pada lobus frontal. Untuk meningkatkan kualitas belajar dan meningkatkan kemampuan berpikir kreatif selayaknya kegiatan pembelajaran tidak hanya dengan duduk melainkan ada aktifitas gerak fisik sehingga mengoptimalkan kinerja lobus frontal sebagai otak berpikir.

\section{Saran}

Untuk mengembangkan keterampilan metakognitif anak usia dini sangat dipengaruhi oleh peran guru maupun orang tua. Staretegi pembelajaran hendaknya bisa mengoptimalkan kinerja otak kanan sehingga bisa mencerdaskan otak kiri (otak berpikir). Dalam proses pembelajaran disarankan melibatkan emosi senang sehingga otak berpikir bekerja dengan optimal. Disamping itu hendaklah menggunakan metode yang melibatkan kreativitas anak yang bermanfaat untuk melatih regulasi diri (kinerja otak kanan) dan akan berdampak pada kemampuan pemecahan masalah. Begitupun kegiatan belajar seharusnya melibatkan aktifitas motorik kasar yang sangat berguna mengalirkan oksigen dalam darah ke otak sehingga dapat meningkatkan kinerja kognitif.

\section{DAFTAR PUSTAKA}

Ardila, C., Corebima, A. D., Zubaidah, S. 2013. Hubungan Keterampilan Metakognitif Terhadap Hasil Belajar Biologi dan Retensi Siswa Kelas X Dengan Penerapan Strategi Pemberdayaan Berpikir Melalui Pertanyaan (PBMP) di SMAN 9 Malang (The Correlation Of Metacognitive Skill On Biology Learning Outcome And Retention Of Students Grade $\mathrm{X}$ Through Thinking Empowerment by Questioning in The State Senior High School 9 in Malang, Indonesia). Online Journal of the State University of Malang, Indonesia.

Bahri, S., Aprian, E. 2008. Peran Pengetahuan Awal, Strategi Kognitif dan Metakognitif terhadap 
Pencapaian Hasil Belajar IPA. Jurnal Serambi Ilmu, 6(1), 58-64.

Burke, Lynsey A. 2012. The impact of a thinking skills intervention on children's concepts of intelligence. Journal Thinking Skills and Creativity Volume 7, Issue 3, December 2012, Pages 145-152

Fatanah, Sidiq. 2016. Masa AUD (3 - 6 tahun): Perkembangan Fisik dan Motorik. Kompasiana 25 November 2016. http://www.kompasiana.com/amp/rancakbana/apakah -anak-kecil-memiliki-teori-dalampikirannya_5834400f6123bd610aee4310. diunggah 8 Desember 2016

Flavell, Jhon H. 1990. Developmental Changes in Young Children's Knowledge About the Mind. Jounal Cognitive Development, Volume 5, issue 1-27. Stanford University.

Goos \& Gilbraith. 2000. A Money Problem : A Source of Insight Into Problem Solving Actioan. Queensland : The University of Queensland

Gracia, Anne. 2014. Hand Book of Spiral Development Maturity. Jakarta:PINT

Ikrar, Taruna., Pharm. 2015. Ilmu Neurosains Modern. Yogyakarta:Pustaka Pelajar.

Iwai, Y. 2011. The Effects of Metacognitive Reading Strategies: Pedagogical Implications for Efl/Esl Teachers [Versi electronik]. The Reading Matrix, 11, 2, 150-159.

Kuswana, Wowo Sunaryo. 2014. Taksonomi Kognitif Perkembangan Ragam Berpikir. Bandung;Remaja Rosdakarya.

Lyon, Lorena. 2016. Development And Validation Of The Memory Complaints Questionnaire. Journal Alzheimer's \& Dementia. Volume 12, Issue 7, Supplement, July 2016, Pages P311

Malone, L.K. 2007. The Convergence of Knowledge Organization, Problem-Solving Behavior, and Metacognition Research with The Modeling Method of Physics Instruction - Part II. Journal Physics Teacher Education.

Marulis, Loren M. et.al..2016. Assessing metacognitive knowledge in 3-5 year olds:the development of a metacognitive knowledge interview (McKI). Jurnal Metacognition Learning. DOI 10.1007/s11409-0169157-7. Springer Science+Business Media New York.

Murdiani, Septriana. 2014. Bahasa Ibu Bahasa Cinta. Bogor:SoU Publiser.

Mutiah, Diana. 2010. Psikologi Bermain Anak Usia dini. Jakarta: Kencana

Ozsoy, G. \& Ataman, A. 2009. The Effect Of Metacognitive Strategy Training On Mathematical Problem Solving Achievement. International
Electronic Journal of Elementary Education, 1, 2, $67-$ 82.

Putri, Desi Hayati. 2013. Memahami Tahap Perkembangan Kemampuan Berpikir Untuk Menciptakan Kurikulum Yang Berorientasi Pada Peningkatan Kemampuan Berpikir Kritis Siswa. http://desihayatiputri.blogspot.co.id/2013/05/memaha mi-tahap-perkembangan-kemampuan.html

Quirk, M. 2006. Intuition and metacognition in medical education: Keys to developing expertise. New York, NY: Springer Publishing Company, Inc.

Sausa, David. 2012. Bagaimana Otak Belajar. Edisi Keempat. Jakarta:Indeks.

Schneider, Wolfgang., Lockl, Kathrin. 2004. Applied Metacognition. Cambridge. University Press.

Suherman dkk. 2001. Strategi Pembelajaran Matematika Kontemporer. Jurusan Pendidikan Matematika UPI. Bandung.

Susanto, Ahmad 2015. Memahami Perilaku Kemandirian Anak Usia Dini. Artikel Fakultas Ilmu Pendidikan. Jakarta: Universitas Muhammadiyah.

Suyadi, 2014. Teori Pembelajaran Anak Usia Dini dalam Kajian Neurosains. Bandung:Remaja Rosdakarya.

Trianingsih, R. 2016. Pengantar Praktik Mendidik Anak Usia Sekolah Dasar. Al Ibtida: Jurnal Pendidikan Guru MI, 3(2), 197-211.

Weimer, Amy A. et.al. 2016. Development of constructivist theory of mind from middle childhood to early adulthood and its relation to social cognition and behavior. Journal of Experimental Child Psychology Volume 154, February 2017, Pages 28-45

Wells, A. 2009. Metacognitive Therapy for Anxiety and Depression. New York, NY: the Guildford Press. Woolfolk

Whitebread, D., Almeqdad, Q., Bryce, D., Demetriou, D., Grau, V., \& Sangster, C. 2010. Metacognition in Young Children: Current Methodological and Theoritical Developments. A. Efklides and P. Misailidi (eds.), Trends and Prospects in Metacognition Research , DOI 10.1007/978-1-44196546-2_11.

Zohar, A. 1999. Teachers' metacognitive knowledge and the instruction of higher order thinking [Versi electronik]. Teaching and Teacher Education, 15, 413-429. 